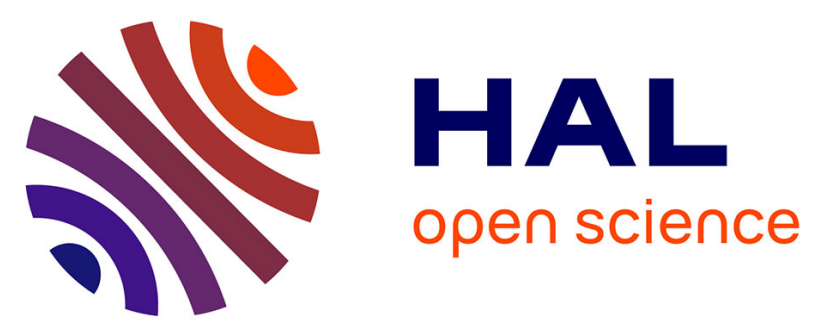

\title{
TRANSFORMATION TOUGHENING IN CERAMICS : MECHANICAL PROPERTIES AND TEMPERATURE DEPENDENCE OF TETRAGONAL POLYCRYSTALLINE ZIRCONIA (TZP)
}

\author{
G. Orange, Gilbert Fantozzi, Y. Bigay, J. Torre
}

\section{To cite this version:}

G. Orange, Gilbert Fantozzi, Y. Bigay, J. Torre. TRANSFORMATION TOUGHENING IN CERAMICS : MECHANICAL PROPERTIES AND TEMPERATURE DEPENDENCE OF TETRAGONAL POLYCRYSTALLINE ZIRCONIA (TZP). Journal de Physique Colloques, 1986, 47 (C1), pp.C1-655C1-659. 10.1051/jphyscol:19861100 . jpa-00225495

\section{HAL Id: jpa-00225495 https://hal.science/jpa-00225495}

Submitted on 1 Jan 1986

HAL is a multi-disciplinary open access archive for the deposit and dissemination of scientific research documents, whether they are published or not. The documents may come from teaching and research institutions in France or abroad, or from public or private research centers.
L'archive ouverte pluridisciplinaire HAL, est destinée au dépôt et à la diffusion de documents scientifiques de niveau recherche, publiés ou non, émanant des établissements d'enseignement et de recherche français ou étrangers, des laboratoires publics ou privés. 
JOURNAL DE PHYSIQUE

Colloque $\mathrm{Cl}$, supplément au $\mathrm{n}^{\circ} 2$, Tome 47, février 1986

page $\mathrm{C} 1-655$

TRANSFORMATION TOUGHENING IN CERAMICS : MECHANICAL PROPERTIES AND TEMPERATURE DEPENDENCE OF TETRAGONAL POLYCRYSTALLINE ZIRCONIA (TZP)

G. ORANGE, G. FANTOZZI, Y. BIGAY* and J.P. TORRE*

Groupe d'Etudes de Métallurgie Physique et de Physique des Matériaux, C.R.R.A.C.S., U.A. 341, I.N.S.A., Bât. 502, F-69621 Villeurbanne Cedex, France

*Céramiques Techniques DESMARQUEST, Laboratoire de Recherche et Développement, 2, Avenue Albert Einstein, F-78190 Trappes, France

\begin{abstract}
Résumé - Des matériaux de type zircone tétragonale polycristalline (TrzP) ont été obtenus par frittage naturel à partir de poudres submicroniques avec additions de faibles quantités $\mathrm{d}^{\prime} \mathrm{Y}_{2} \mathrm{O}_{3}$. Ies propriétés mécaniques ont été déterminees en fonction de la température (jusqu'à $900^{\circ} \mathrm{C}$ ). Ainsi la ténacité (environ $10 \mathrm{MPa} \sqrt{\mathrm{m}}$ à température ambiante) décroît linéairement de $200^{\circ}$ à $600^{\circ} \mathrm{C}$. Les résultats sont discutés, en termes de mécanismes de renforcement (transformation de phase), en fonction de la microstructure et de la stabilité de la phase tétragonale.
\end{abstract}

Abstract - Polycrystalline tetragonal zirconia materials (TZP) have been obtained by normal sintering from submicronic powders with low additions of $\mathrm{Y}_{2} \mathrm{O}_{3}$. Mechanical properties have been studied as a function of temperature, up to $900^{\circ} \mathrm{C}$. Fracture toughness (about $10 \mathrm{MPa} / \mathrm{m}$ at room temperature) decreases linearly from $200^{\circ}$ to $600^{\circ} \mathrm{C}$. Results are discussed according to toughening mechanisms (phase transformation) on the basis of the microstructure and stability of the tetragonal phase.

\title{
I - INTRODUCTION
}

The application of phase transformations to enhance toughness of ceramic materials has been studied first in the case of partially stabilized zirconia (P.S.Z.). In these ceramics, the metastable phase is present as fine coherent precipitates in a large-grain cubic matrix $/ 1,2 /$. These materials are usually made by sintering in the cubic/tetragonal field followed by controlled precipitation treatments, or in a single step process by sintering in the cubic/tetragonal field. In both cases, the microstructure is made up of large grains (cubic phase), and this is a limiting factor for mechanical properties. Furthermore, these properties are strongly dependent on thermal history of the material.

With an accurate control of grain size and additives content, single phase tetragonal zirconia materials (TZP) can be obtained /3/. In this type of material the toughening phase, i.e. the phase which leads to energy absorption by stress-induced transformation, is not restricted because all the material is in the tetragonal form : also, the toughening effect can be potentially maximized and the fracture toughness is considerably increased compared to all other P.S.Z.. 
Furthermore, the grain size is very fine (between 0.1 and $1 \mu \mathrm{m}$ ), and the fracture strength can also be considerably enhanced. Main results have been obtained with small $\mathrm{Y}_{2} \mathrm{O}_{3}$ additions ( $\mathrm{Y}$-TZP), and a dependence of mechanical behaviour on $\mathrm{Y}_{2} \mathrm{O}_{3}$ content has been observed $/ 4 /$; the effect of raw powder characteristics and sintering conditions has also been reported $/ 5,6 /$. Thus, it has been observed that Y-TZP fracture strength increases if the tetragonal grain size is reduced, whereas fracture toughness is maximized at the largest possible tetragonal grain size - for a given $\mathrm{Y}_{2} \mathrm{O}_{3}$ content -.

All high $\sigma_{f}$ and $K_{l c}$ values of TZP reported are concerned with room temperature conditions. In this work, we have observed the mechanical properties temperature dependence of Y-TZP materials. The results are discussed in view of the theoretical predictions based on the variation of chemical free energy change /7/.

\section{II - EXPERTMENTAL PROCEDURE}

II-I - Material

Materials studied are fine grained tetragonal zirconia with 5.2 wt $8 \mathrm{Y}_{2} \mathrm{O}_{3}$ ( $\sim 3$ mole 8). Two batches have been obtained ( $Y$-TZP 1 and $Y-T Z P$ 2) by pressureless sintering $\left(1500^{\circ} \mathrm{C}-4 \mathrm{~h}\right)$ from mixed submicron powders. Only milling conditions have been

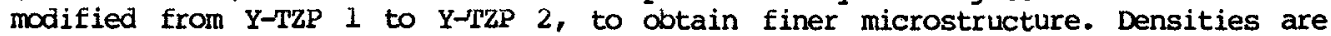
about 94 to 96.58 of theoretical density, and the mean grain size is between 0.65 and $0.8 \mu \mathrm{m}$.

Relative contents of tetragonal and monoclinic phases have been calculated by $\mathrm{x}$-Ray aiffraction frosn (III) $\mathrm{m}$, (III) $\mathrm{m}$ and (III)t reflexion intensities $/ 8 /$.

\section{II-2 - Mechanical experiments}

The fracture strength $\left(\sigma_{\mathrm{f}}\right)$ and the fracture toughness $\left(k_{1 C}\right)$ values have been obtained with 3 points bending tests ( $15 \mathrm{~mm}$ span), at a cross-head speed of 0.1 $\mathrm{mm} / \mathrm{min}$. Specimens $\left(4 \times 3 \times 22 \mathrm{~mm}^{3}\right)$ were machined and polished $(6 \mu \mathrm{m}$ and $1 \mu \mathrm{m}$ diamond paste) from sintered bodies. $K_{1 C}$ measurements have been performed on notched beans (S.E.N.B.) with a straight through notch of $1.6 \mathrm{~mm}$ depth $(a / w \simeq 0.4)$ and a tip radius of $80 \mu \mathrm{m}$. To eliminate induced residual stresses, annealing treatments at $950^{\circ} \mathrm{C} \mathrm{(15} \mathrm{min}$ ) have been made with all the specimens. Experiments were performed in air,up to $900^{\circ} \mathrm{C}$, with a special high temperature testing apparatus $/ 9 \%$

\section{III - RESULIS}

In the studied $Y$-TZP materials case, we did not observe any significant amount of cubic (c) phase. The tetragonal phase proportion is between 788 and 908 in as machined specimens and increases, in all specimens, to values higher than 958 after $950^{\circ} \mathrm{C}$ annealing.

Room temperature mechanical characteristics are similar to those reported for similar materials $14,10,11 \%$. The high toughness values $(\sim 10 \mathrm{MPa} \sqrt{\mathrm{m}})$ can be correlated to the contribution of a stress-induced phase transformation to the fracture energy. This mechanism is confirmed by a systematic analysis of the different cristallographic varieties : one observes a reduction of the tetragonal phase proportion from $95 \%$ (before fracture) to 658 on fracture faces $/ 12 /$. According to the thermodynamic approach proposed by F.F. LANGE, the phase transformation toughening effect can be expressed as, $/ 13 /$ :

$$
K_{C}{ }^{2}-K_{O}^{2}=\frac{2 R E_{C} V_{i}\left(\left|\Delta G_{C}\right|-\Delta U_{S e} \cdot f\right)}{1-\nu_{c}^{2}}
$$




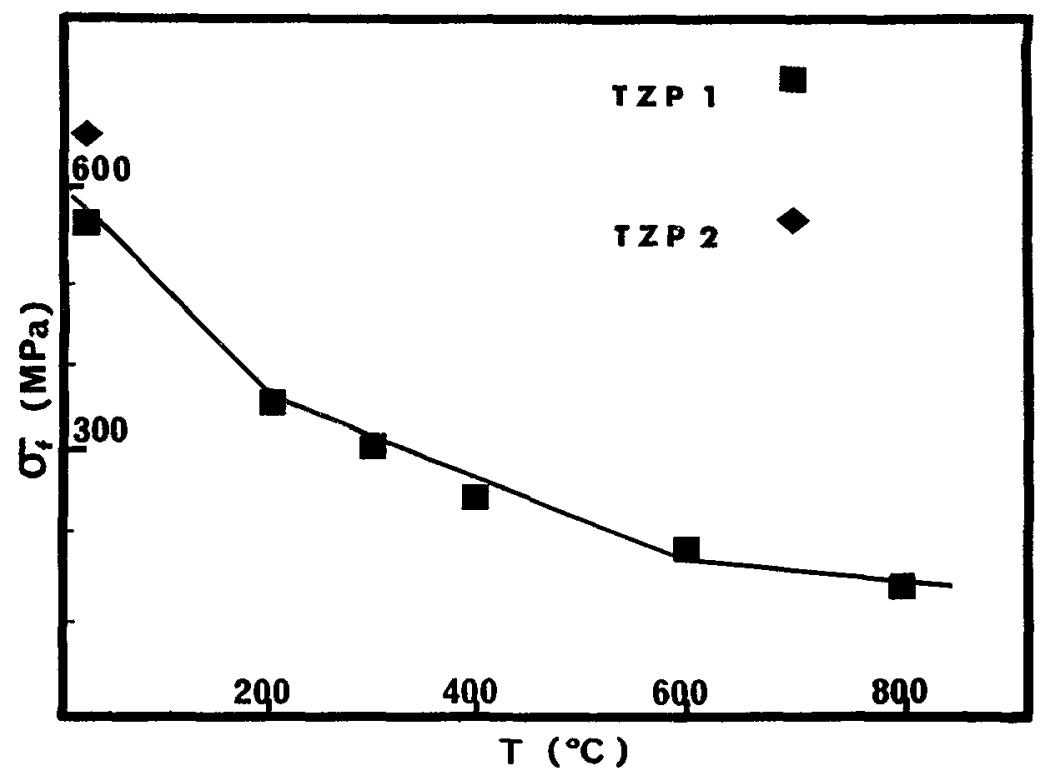

Fig. 1 - Fracture strength temperature dependence of Y-TZP material

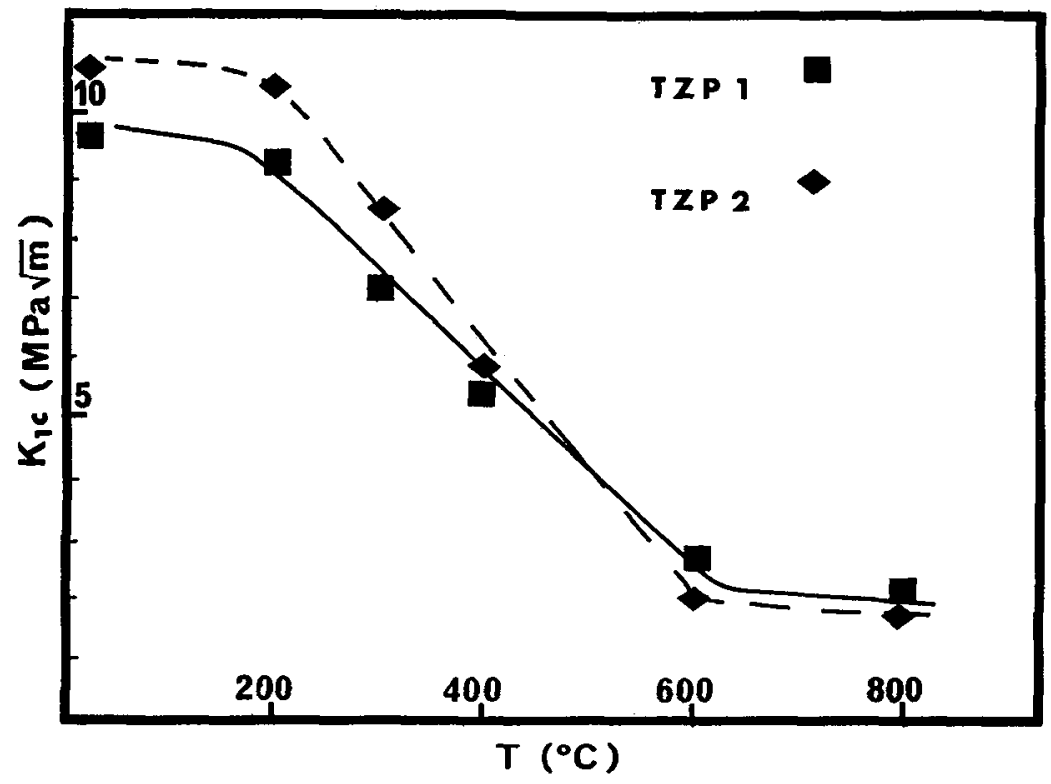

F1g. 2 - Influence of temperature on the fracture toughness of Y-TZP materials 
With $\mathrm{K}_{\mathrm{O}}=3 \mathrm{MPa} \sqrt{\mathrm{m}}$ (toughness of material without any transformation toughening phenomenon), $V i=958$ (volume fraction of retained tetragonal phase), $\mathrm{E}_{\mathrm{C}}=180 \mathrm{GPa}$, $\nu_{C}=0.25$ and $R=0.8 \mu \mathrm{m}$ (size of the transformation zone associated with the crack), one obtains (for $\mathrm{K}_{\mathrm{C}}=9.2 \mathrm{MPa} \sqrt{\mathrm{m}}$ ) $: \Delta \mathrm{G}_{\mathrm{C}}-\mathrm{f} \cdot \Delta \mathrm{U}_{\mathrm{se}}=258 \mathrm{M} . \mathrm{J} . \mathrm{m}^{-3}$. This value expresses the work done, per unit volume, by the stress field to induce the transformation. Microstructure observations of TZP materials reveal the presence of twinning in transformed (monoclinic) grains and of microcracks along grain boundaries $/ 13 /$. This point contributes to relieving strain energy during fracture and so increases the term $\left(\Delta \mathrm{G}_{\mathrm{Cl}}-\Delta \mathrm{U}_{\mathrm{se}} \cdot \mathrm{f}\right)$ in equation (1) : this can explain the high toughness values we observed. However, the fracture strength values (Y-TZP 1 and Y-TZP 2) are quite low if compared to other T.Z.P.: this is due to the presence of important residual porosity $(d=95 \% d$ th) and also the presence of large inclusions (from raw powder and milling media). According to these observations, processing has been slightly modified and one observes, on new TZP batches (*), fracture strength values of about $1000 \mathrm{MPa}$.

The influence of temperature on mechanical properties is illustrated in fig. 1 and fig. 2. The fracture toughness decreases quite linearly between $200^{\circ} \mathrm{C}$ and $600^{\circ} \mathrm{C}$, and is similar to that one of stabilized zirconia at $800^{\circ} \mathrm{C}$. The fracture strength variation is similar, except an important decrease at about $200^{\circ} \mathrm{C}$. This low temperature degradation can be correlated to an activated formation of monoclinic phase on the specimens surface. Such a behaviour has been reported by different authors, and seems to reach a maximum at $200^{\circ} \mathrm{C} / 14 /$. The decrease of $\mathrm{K}_{\mathrm{lc}}$ with temperature is similar to the chemical free energy change $\left(\left|\Delta G_{c}\right|\right.$ ) temperature dependence : for the tetragonal $\longrightarrow$ monoclinic transformation, $\left|\Delta G_{C}\right|$ decreases with increasing temperature.

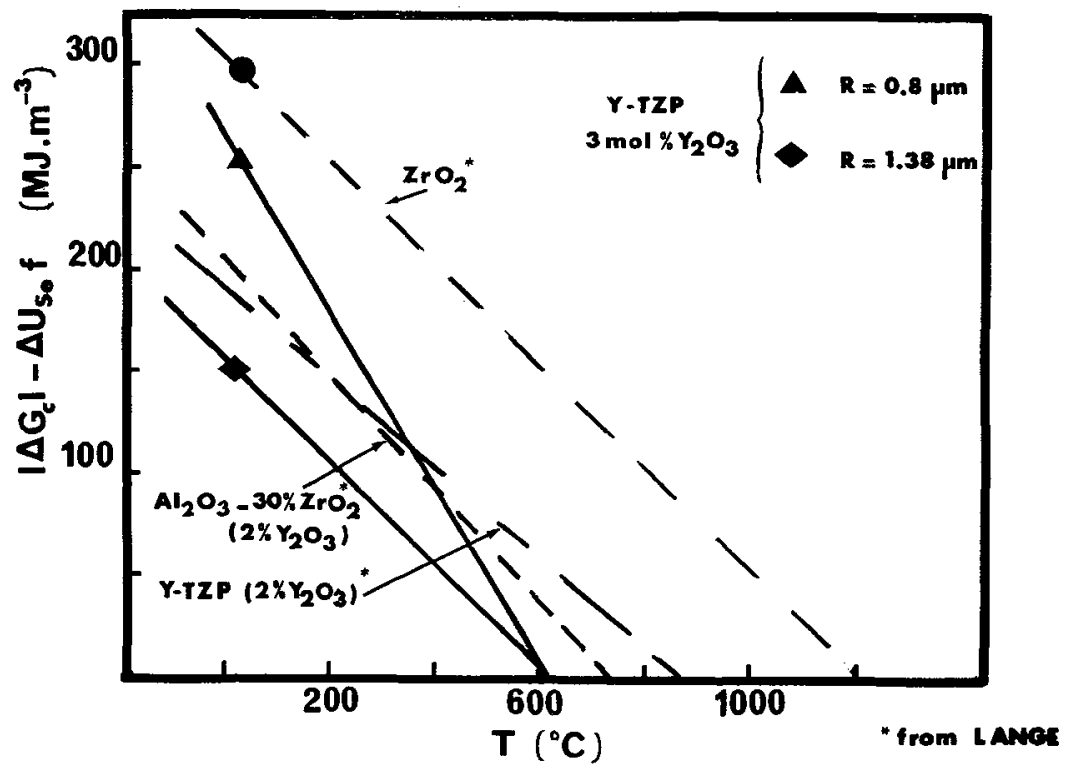

Fig. 3 - work (per unit volume) to induce the transformation versus temperature

The critical temperature $\mathrm{To}$, i.e. the temperature corresponding to the value $\left(\left|\Delta \mathrm{G}_{\mathrm{C}}\right|\right.$ - $\left.\Delta U_{\text {se. }} f\right)=0$, is defined in our materials at about $625^{\circ} \mathrm{C}$ : there is no more toughening effect at higher temperatures and $\mathrm{K}_{\mathrm{c}}=\mathrm{k}_{\mathrm{O}}$ (equ. (1)). Whe have plotted

(*) ZFYYT grade : DFSMARQUEST CERAMIQUE TECHNIQUE - 27025 EVREUX (France) 
calculated values of $\left(\left|\Delta G_{C}\right|-f \Delta U_{S e}\right)$ versus temperature in Fig. 3; some results reported by Lange have also been plotted in Fig. $3 / 7 /$. However, because $\Delta G_{C}$ is the greatest temperature dependence factor in Equ. (1), the slope must be nearly the same as d $\mid \Delta \mathrm{G}_{\mathrm{C}} / \mathrm{dT}$ for pure $\mathrm{ZrO}_{2} / 15 \%$. Recalculated values of $\left(\Delta \mathrm{G}_{\mathrm{C}^{-}} \Delta \mathrm{U}_{\mathrm{se}}\right.$. $\left.\mathrm{f}\right)$ with $R=1.38 \mu \mathrm{m}$ give a resulting slope in good agreement with reported thermodynamic data $\left(0,248 \mathrm{MJ} . \mathrm{m}^{-3} . \mathrm{C}^{-1}\right)$, and the new value of $\left|\triangle G_{\mathrm{C}}\right|$ at room temperature is about $150 \mathrm{MJ}$. $\mathrm{m}^{-3}$. This new value is slightly lower than the calculated value for hot-pressed Y-TZP with 2 molez $\mathrm{Y}_{2} \mathrm{O}_{3}\left(188 \mathrm{MJ}^{-3}\right) / 7 /$. This is consistent with the effect of alloy content $:\left|\Delta G_{c}\right|$ decreases with increasing $\mathrm{Y}_{2} \mathrm{O}_{3}$.

\section{IV - CONCLUSION}

- High toughness values $(10 \mathrm{MPa} \sqrt{\mathrm{m}})$ have been obtained in pressureless sintered tetragonal zirconia materials ( $Y-T Z P)$. The toughening effect can be explained by the contribution of a stress-induced phase transformation.

- In the materials studied, the critical temperature is $625^{\circ} \mathrm{C}$. The energy change at room temperature associated with the transformation is about $150 \mathrm{MJ} . \mathrm{m}^{-3}$, with a transformation zone size of $1.38 \mu \mathrm{m}$. Results are consistent with thermodynamic data.

\section{REFGRENCES}

II Garvie, R.C., Hannink, R.H.J. and Pascoe, R.T., Nature 258 (1975) 703.

/2/ Porter, D.L. and Heuer, A.H., J. Arn. Ceram. Soc. 60 (1977) 183.

13/ Gupta, T.K., Bechtold, J.H., Kuznicki, R.C., Cadoff, L.H. and Rossing, B.R., J. Mater. Sci. 21 (1977) 2421.

14/ Tsukuma, K., Kubota, Y. and Tsukidate, T., Science and Technology of Zirconia 2, Advances in Ceramics Vol. 12, ed. Claussen N., Rühle M. and Heuer A.H., (1984) 382.

15/ Rïhle, M., Claussen, N. and Heuer, A.H., ibid., 352.

/6/ Matsui, M., Soma, T., and Oda, I., ibia., 371.

77) Lange, F.F., J. Mater. Sci. 17 (1982) 255 (Part. 5).

18/ Garvie, R.C. and Nicholson, P.S., J. Am. Ceram. Soc. 55 (1972) 303.

19/ Orange, G., Dubois, J., Fantozzi, G. and Gobin, P.F., Mem. Sci. Rev. Met. 2 (1980) 131 .

/10/ Gupta, T.K., Lange, F.F. and Bechtold, J.H., J. Mater. Sci. 13 (1978) 1464.

/11 Lange, F.F., J. Mater. Sci. 17 (1982) 240 (Part. 3).

112/ Orange, G. and Fantozzi, G., Fourth Inter. Conf. On Fracture Mechanics of Ceramics (Blacksburg), June 1985, U.S.A. To be published.

113/ Lange, F.F., J. Mater. Sci. 17 (1982) 225 (Part. 1) and 235 (Part. 2).

/14/ Sato, T., Ohtaki, S. and Shimada, M., J. Mater. Sci. 20 (1985) 1466.

115/ Whitney E.D., J. Am. Ceram. Soc. 45 (1962) 612. 